(C). П. Посохова, О. Ю. Кучеренко, К. О. Ніточко

Одесъкий національний медичний університет

\title{
ГІПОКСИЧНО-ІШЕМІЧНЕ УШКОДЖЕННЯ ГОЛОВНОГО МОЗКУ ПЛОДА: ПРОГНОЗУВАННЯ ТА ПОПЕРЕДЖЕННЯ
}

Мета дослідження - вивчити вплив фракторів ризику в матері та захворюваності у неонатальному періоді на розвиток гіпоксично-ішемічної енцесралопатії (ГІЕ) новонароджених залежно від їх гестаційного віку, а також дослідити вплив нейропротекції на розвиток гіпоксичних уражень головного мозку в недоношених новонароджених.

Матеріали та методи. На першому етапі проведено ретроспективний аналіз перебігу вагітності, пологів та стану новонароджених у 150 жінок, діти яких перенесли гіпоксично-ішемічне ураження головного мозку. I групу (ІГ) склали 62 жінки, які народили доношених дітей, II групу (IIГ) - 88 жінок, які народили передчасно у терміні 26+6-33+6 тижнів гестації. На другому етапі проспективно досліджено рівень нейроспецифрічних маркерів пошкодження нервової тканини (NSE та S100) у 60 недоношених новонароджених у термінах гестації до 32 тижнів, які були розподілені на дві групи. Основну групу (ОГ) склали 30 недоношених новонароджених, матерям яких вводили сульфат магнію з метою нейропротекції, групу порівняння (ПГ) - 30 недоношених новонароджених, матері яких із різних причин нейропротекцію не отримали.

Результати дослідження та їх обговорення. До факторів ризику народження дітей із ГІЕ належать екстрагенітальна патологія у матері (ВШ 1090,818, 95 \% ДІ 64,501-18 447,401), урогенітальні інсеекції - хламідіоз (ВШ 21,87, 95 \% ДІ 1,264378,397), недоношеність, низька маса тіла при народженні, ПРПО, хоріонамніоніт (ВШ 17,6, 95 \% ДІ 2,288-135,407), оцінка за шкалою Апгар <7 балів, захворюваність у неонатальному періоді. Нейроспецифічна енолаза (NSE) була вірогідно вища у дітей із терміном гестації до 32 тижнів та оцінкою за Апгар менше 6 балів. Нижча концентрація білка S100 у новонароджених основної групи може пояснюватись захисною дією сульфату магнію на ЦНС недоношеного новонародженого.

Висновки. До фракторів ризику неврологічних порушень у новонароджених належать екстрагенітальна патологія, урогенітальні інфекції у матері, недоношеність, передчасний розрив плодових оболонок, розвиток хоріонамніоніту, затримка росту плода. Проведення нейропротекції сульфатом магнію перед розродженням є важливим заходом попередження гіпоксично-ішемічного ушкодження головного мозку плода та недоношеного новонародженого.

Ключові слова: гіпоксично-ішемічна енцефралопатія; недоношеність; передчасні пологи; хоріонамніоніт; нейропротекція.

ГИПОКСИЧЕСКИ-ИШЕМИЧЕСКОЕ ПОВРЕЖДЕНИЕ ГОЛОВНОГО МОЗГА ПЛОДА: ПРОГНОЗИРОВАНИЕ И ПРЕДУПРЕЖДЕНИЕ

Цель исследования - изучить влияние факторов риска у матери и заболеваемости в неонатальном периоде на развитие гипоксически-ишемической энцесралопатии (ГИЭ) новорожденных в зависимости от их гестационного возраста, а также определить влияние нейропротекции на развитие гипоксических поражений головного мозга у недоношенных новорожденных.

Материалы и методы. На первом этапе проведен ретроспективный анализ течения беременности, родов и состояния новорожденных у 150 женщин, дети которых перенесли гипоксически-ишемическое поражение головного мозга. I группу (I Г) составили 62 женщины, родившие доношенных детей, II группу (II Г) - 88 женщин, родивших преждевременно в сроке 26+6-33+6 недель гестации. На втором этапе проспективно исследован уровень нейроспецисических маркеров повреждения нервной ткани (NSE и S100) у 60 недоношенных новорожденных в сроках гестации до 32 недель, которые были разделены на две группы. Основную группу (ОГ) составили 30 недоношенных новорожденных, матерям которых вводился сульфат магния с целью нейропротекции, группу сравнения (СГ) - 30 недоношенных новорожденных, матери которых по разным причинам нейропротекцию не получили.

Результаты исследования и их обсуждение. К факторам риска рождения детей с ГИЭ относятся экстрагенитальная патология у матери (ОШ 1090,818, 95 \% ДИ 64,501-18 447,401), урогенитальные инсрекции - хламидиоз (ОШ 21,87, 95 \% ДИ 1,264-378,397), недоношенность, низкая масса тела при рождении, ПРПО, хорионамнионит (ОШ 17,6, 95 \% ДИ 2,288-135,407), оценка по шкале Апгар <7 баллов, заболеваемость в неонатальном периоде. Нейроспецисрическая энолаза (NSE) была достоверно выше у детей со сроком гестации до 32 недель и оценкой по Апгар <6 баллов. Более низкая концентрация белка S100 у новорожденных основной группы может объясняться защитным действием сульфата магния на ЦНС недоношенного новорожденного.

Выводы. К факторам риска неврологических нарушений у новорожденных относятся экстрагенитальная патология, урогенитальные инфекции у матери, недоношенность, преждевременный разрыв плодных оболочек, развитие хорионамнионита, задержка роста плода. Проведение нейропротекции сульфатом магния перед родоразрешением является важной мерой предупреждения гипоксически-ишемического повреждения головного мозга плода и недоношенного новорожденного.

Ключевые слова: гипоксически-ишемическая энцефралопатия; недоношенность; преждевременные роды; хорионамнионит; нейропротекция.

HYPOXIC-ISCHEMIC FETAL BRAIN INJURY: FORECASTING AND PREVENTION

The aim of the study - to investigate the influence of risk factors in the mother and morbidity in the neonatal period on the development of hypoxic-ischemic encephalopathy of newborns, depending on their gestational age, as well as to determine the effect of neuroprotection on the development of hypoxic brain lesions in premature infants.

Materials and Methods. At the first stage, a retrospective analysis of the course of pregnancy, childbirth and the condition of newborns was carried out in 150 women whose children had suffered from hypoxic-ischemic brain damage. Group I (GI) consisted 
of 62 women who gave birth to full-term babies, Group II (GII) - 88 women who gave birth prematurely at 26+6-33+6 weeks of gestation. At the second stage, the level of neurospecific markers of nerve tissue damage (NSE and S100) was prospectively investigated in 60 preterm infants at gestational terms up to 32 weeks, who were divided into two groups. The main group (MG) consisted of 30 preterm infants whose mothers were injected with magnesium sulfate for the purpose of neuroprotection, the comparison group (CG) - 30 preterm infants whose mothers did not receive neuroprotection for various reasons.

Results and Discussion. The risk factors for the birth of children with HIE include extragenital pathology in the mother (OR 1090.818, 95 \% Cl 64.501-18447.401), urogenital infections - chlamydia (OR 21.87, 95 \% Cl 1.264 - 378.397), prematurity, low weight bodies at birth, PROM, chorionamnionitis (OR 17.6, $95 \% \mathrm{Cl} 2.288$ - 135.407), Apgar score <7 points, morbidity in the neonatal period. Neurospecific enolase (NSE) was significantly higher in children with gestational age up to 32 weeks and an Apgar score of $<6$ points. The lower concentration of protein $\mathrm{S} 100$ in newborns of the main group can be explained by the protective effect of magnesium sulfate on the central nervous system of a premature newborn.

Conclusions. Risk factors for neurological disorders in newborns include extragenital pathology, urogenital infections of the mother, prematurity, premature rupture of the membranes, the development of chorionamnionitis, and fetal growth retardation. Conducting neuroprotection with magnesium sulfate before delivery is an important measure to prevent hypoxic-ischemic brain damage to the fetus and premature newborn.

Key words: hypoxic-ischemic encephalopathy; prematurity; preterm labor; chorionamnionitis; neuroprotection.

ВСтУп. Упродовж двох останніх десятиріч відзначається тривожна тенденція: при зменшенні кількості здорових дітей в Україні спостерігається щорічне зростання кількості дітей з інвалідністю, у середньому на 16 тисяч дітей, або з щорічним приростом 0,5\% [1-3]. Інвалідність дитячого населення є однією з найбільш актуальних проблем, оскільки вона є медичною, соціальною, психологічною, економічною проблемою і має державне значення. Піклування суспільства про інвалідів дитинства триває довгі роки. На 1-му місці залишаються уроджені аномалії, десормації й хромосомні порушення, 2-ге місце посідають розлади психіки й поведінки, а на 3-му місці - хвороби центральної нервової системи, показник яких складає 61,64 на 1000 народжених, а показник дитячого церебрального паралічу (ДЦП) - 0,13 [4-6].

Згідно зі статистикою, 65 \% випадків пошкоджень ЦНС у новонароджених зумовлені гіпоксично-ішемічними порушеннями і тільки 15 \% припадають на різні постнатальні та генетичні фрактори [6]. Ураження нервової системи призводять до дитячої інвалідності в 20,6 \% випадків, при цьому в 70-80 \% випадків вони зумовлені перинатальними фракторами [7, 8].

На сучасному етапі було виявлено ряд фракторів ризику ГІЕ, які можна згрупувати за такими категоріями: соціально-демографрічні фрактори, стан здоров'я матері, перебіг вагітності та ускладнення, стан фето-плацентарного комплексу, стан плода, перебіг пологів та ускладнення, стан новонародженого, якість надання медичної допомоги у закладах охорони здоров'я $[9,10]$.

Одним із найтяжчих перинатальних наслідків ГIE $€$ розвиток дитячого церебрального паралічу. Загальна поширеність ДЦП становить приблизно 2 на 1000 живонароджених. Поширеність ДЦП набагато вища у недоношених порівняно з доношеними дітьми та зростає із зменшенням терміну вагітності та маси тіла (МТ) при народженні [11-14].

Частота ДЦП залежить від гестаційного віку (ГВ): ГВ<28 тижнів - 82 на 1000 живонароджених, ГВ від 28 до 31 тижня - 43 на 1000 живонароджених, ГВ від 32 до 36 тижнів - 6,8 на 1000 живонароджених, гВ>36 тижнів - 1,4 на 1000 живонароджених.

Частота ДЦП залежить від маси тіла при народженні: <1500 г - 59,2 на 1000 живонароджених, від 1500 до 2499 г - 10,2 на 1000 живонароджених, >2500 г - 1,33 на 1000 живонароджених. У великих епідеміологічних дослідженнях дітей із ДЦП приблизно 25 \% були дуже недоношеними (ГВ<32 тижні), 10-20 \% були помірно передчасними або пізно недоношеними (ГВ 32-36 тижнів), а 60 \% народилися в термін (ГВ>36 тижнів) [15, 16].

Метааналіз 26 обсерваційних досліджень показав, що як клінічний, так і гістологічний хоріонамніоніт були пов'язані з підвищеним ризиком розвитку ДЦП (відносний ризик [RR] 1,9, 95 \% ДІ 1,5-2,5) [17]. Інше дослідження «випадок - контроль» показало, що будь-яка інсрекція матері під час вагітності була пов'язана 3 підвищеним ризиком розвитку ДЦП (АБО 2,9, 95 \% ДІ 1,7-4,8) і що неонатальна інфекція була сильним незалежним предиктором ДЦП (АБО 14,7, 95 \% ДІ 1,7- 126,5) [18].

Таким чином, недоношеність, внутрішньоутробна та інтранатальна гіпоксія плода мають багатофакторну етіологію, що призводить до неонатальної гіпоксичноішемічної енцефралопатії з несприятливими наслідками.

МЕТА ДОСЛІДЖЕННЯ - вивчити вплив фракторів ризику у матері та захворюваності у неонатальному періоді на розвиток гіпоксично-ішемічної енцефралопатії новонароджених залежно від їх гестаційного віку, а також дослідити вплив нейропротекції на розвиток гіпоксичних уражень головного мозку в недоношених новонароджених.

МАТЕРІАЛИ ТА МЕТОДИ. Нами був проведений ретроспективний аналіз перебігу вагітності, пологів та стану новонароджених у 150 жінок, діти яких перенесли гіпоксично-ішемічне ушкодження головного мозку під час вагітності та пологів, як наслідок - затримка розумового і фрізичного розвитку, неврологічні захворювання та дитячий церебральний параліч. Залежно від терміну розродження ми виділили дві групи: першу групу (I Г) склали 62 (42,3 \%) жінки, які народили доношених дітей, другу групу (II Г) склали 88 (58,7 \%) жінок, які народили передчасно у терміні від 26+6 до 33+6 тижнів гестації.

Середній вік жінок в обох групах не відрізнявся і склав $(28,9 \pm 2,6)$ року. Шкідливі звички, як-от куріння, мали більше 30 \% жінок в обох групах. Відношення шансів (ВШ) у разі шкідливих звичок у вагітних, як-от куріння/алкоголь, було 4,128 (95 \% ДІ 1,129-15,094).

РЕЗУЛЬТАТИ ДОСЛІДЖЕННЯ ТА ЇХ ОБГОВОРЕННЯ. Як свідчать наші дані, вагітні жінки з II Г, які народили передчасно, вірогідно частіше порівняно $з$ жінками 3 I Г мали такі екстрагенітальні захворювання, як загострення 
хронічного пієлонесриту (15,8 \%), гострі респіраторні інфрекції під час вагітності (18,2 \%), захворювання органів дихання (15,9\%), туберкульоз легень (4,5 \%), ВІЛінорекція (9,1\%) і оперативне втручання (апендектомія) у 2,2 \% жінок. Інфекційний фрактор у жінок II Г міг бути пусковим для передчасних пологів та народження недоношених дітей.

Відношення шансів (ВШ) у вагітних з екстрагенітальною патологією, діти яких хворіють на ДЦП, було великим (ВШ 1090,818, 95 \% ДІ 64,501-18 447,401), що свідчить про несприятливий прогноз для дітей, матері яких мають екстрагенітальну патологію.

Однією з причин невиношування вагітності та передчасних пологів є урогенітальна інфекція у вагітних.

Передчасним пологам у вагітних II Г сприяли наявність таких генітальних інфеекцій, як хронічний кандидоз (29,5\%), трихомоніаз (15,9\%), сифріліс (9,1\%), бактеріальний вагіноз (10,2 \%), ВІЛ-інфекція $(9,1 \%)$. Всього майже 70 \% вагітних з ІІ Г мали урогенітальні інфекції під час вагітності (табл. 1). Дані інсрекції не лікували майже у 50 \% пацієнток впродовж вагітності.
У разі наявності генітальних інфекцій у вагітних обох груп відношення шансів було таким: хронічний кандидоз (ВШ 2,352, 95 \% ДІ 0,973-5,686), трихомоніаз (ВШ 4,809, 95 \% дІ 0,228-101,408), хламідіоз (ВШ 21,87, 95 \% ДІ 1,264-378,397), ВІЛ-інфекція (ВШ 2,858, 95 \% ДІ 0,115-70,978).

Пологи в обох групах нашого спостереження перебігали з ускладненнями (табл. 2). Так, передчасний розрив плодових оболонок був у 73 (48,6 \%) вагітних в обох групах, що в 4 рази більше, ніж у І КГ. Безводний проміжок більше 48 год та хоріонамніоніт був майже у третини жінок з II РГ, що сприяло внутрішньоутробному інсрікуванню та гіпоксичному ураженню головного мозку. Тривалий безводний проміжок більше 168 год був у 6 (6,8 \%) вагітних із ІІ РГ. Так, ВШ до ДЦП при безводному проміжку більше 24 год склало 6, 255 (95\% ДІ 1,363-28,701), у разі розвитку хоріонамніоніту ВШ 17,6 (95 \% ДІ 2,288-135,407). Наведені вище дані підтверджують роль інфекційного фактора у розвитку гіпоксично-ішемічної енцефалопатії (рис. 1).

Важливе значення для розвитку ГІЕ новонароджених має термін гестації. Незрілий головний мозок плода осо-

Таблиця 1. Урогенітальна інфекція в обстежених жінок обох груп

\begin{tabular}{|c|c|c|c|c|}
\hline \multirow[t]{2}{*}{ Урогенітальна інсрекція } & \multicolumn{2}{|c|}{$\begin{array}{c}\text { Перша група } \\
\text { Термінові пологи } \\
\text { n=62 }\end{array}$} & \multicolumn{2}{|c|}{$\begin{array}{c}\text { Друга група } \\
\text { Передчасні пологи } \\
\text { n=88 }\end{array}$} \\
\hline & абс. & $\%$ & абс. & $\%$ \\
\hline Бактеріальний вагіноз & 4 & 6,4 & 9 & 10,2 \\
\hline Хламідіоз & 3 & 4,8 & 10 & $11,3^{*}$ \\
\hline Трихомоніаз & 4 & 6,4 & 14 & $15,9^{*}$ \\
\hline Хронічний кандидоз & 8 & 12,9 & 26 & $29,5^{\star}$ \\
\hline Сифріліс & 2 & 3,2 & 8 & $9,1^{*}$ \\
\hline Генітальний герпес & 1 & 1,6 & 3 & 3,4 \\
\hline Всього & 22 & $35,4^{\star *}$ & 61 & $69,3^{* \star}$ \\
\hline
\end{tabular}

Примітка. Достовірність відносно групи Г। * - p<0,05.

Таблиця 2. Перебіг пологів у обстежених вагітних

\begin{tabular}{|c|c|c|c|c|}
\hline \multirow[t]{2}{*}{ Перебіг пологів } & \multicolumn{2}{|c|}{$\begin{array}{c}\mathrm{I} \Gamma \\
\mathrm{n}=62\end{array}$} & \multicolumn{2}{|c|}{$\begin{array}{c}11 \Gamma \\
n=88\end{array}$} \\
\hline & абс. & $\%$ & абс. & $\%$ \\
\hline ПРПО (2-48 год) & 12 & $19,3^{\star *}$ & 12 & $13,5^{\star \star}$ \\
\hline ПРПО (48-168 год) & 4 & 6,5 & 20 & $22,7^{*}$ \\
\hline ПРПО (>168 год) & 0 & 0 & 6 & 6,8 \\
\hline Хоріонамніоніт & 2 & 3,2 & 26 & $29,5^{*}$ \\
\hline Тазове передлежання & 4 & 6,5 & 9 & 10,2 \\
\hline Передчасне відшарування нормально розташованої плаценти & 8 & 12,9 & 12 & 13,6 \\
\hline Передлежання плаценти, кровотеча & 2 & 3,2 & 2 & 2,3 \\
\hline Туге обвиття пуповиною навколо шиї & 3 & 4,8 & 7 & 7,9 \\
\hline Родозбудження/родопосилення & 8 & $12,9^{\star \star}$ & 22 & 25,0 ** \\
\hline Слабкість пологової діяльності & 6 & 9,6 & 10 & 11,3 \\
\hline Стрімкі пологи & 2 & 3,2 & 8 & $9,1^{*}$ \\
\hline Дистрес плода & 38 & $45,2^{\star \star}$ & 41 & $46,5^{\star \star}$ \\
\hline Кесаревий розтин (плановий) & 4 & 6,4 & 7 & 7,9 \\
\hline Ургентний кесаревий розтин & 17 & $27,4^{\star \star}$ & 23 & $26,1^{\star \star}$ \\
\hline Акушерські щипці & 6 & 9,7 & 0 & 0 \\
\hline Вакуум-екстракція плода & 4 & 6,4 & 2 & 2,2 \\
\hline
\end{tabular}

Примітка. Достовірність відносно групи Г। * - p<0,05. 


Бактеріальний вагіноз
Кандидоз
Трихомоніаз
Хламідіоз
ВІЛ-інфрекція
Екстрагенітальна патологія
Захворювання нирок
Total (fixed effects)
Total (random effects)

Рис. 1. Ризик народження дітей із ГІЕ в обстежених вагітних.

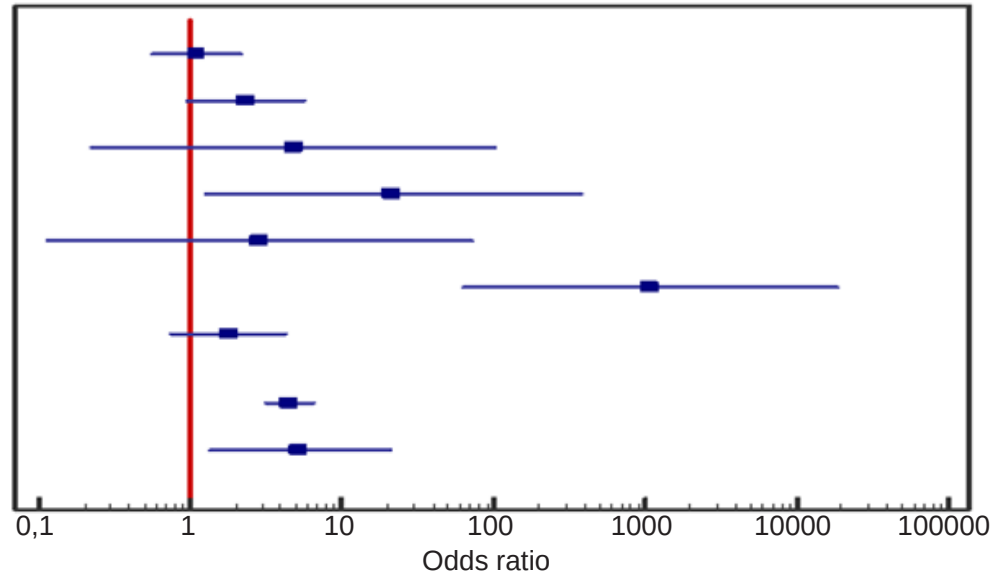

Odds ratio бливо чутливий до всіх фракторів, що можуть виникнути під час вагітності та пологів. Виходячи 3 наших даних, вагітні 3 групи II народили 24 (27,3\%) дітей з екстремально низькою масою тіла у терміні гестації 27-30 тижнів вагітності, які мали гіпоксично-ішемічне ушкодження головного мозку.

Оцінка за Апгар є прогностичним фрактором ГIE новонароджених. Так, серед 150 дітей обох груп, оцінку за Апгар на 1-й та 5-й хв 2-3 бали мали - 12-8 \%, 4-5 балів - 38-25,4 \%, 6 балів - 58-38,6 \%, 7 і вище - 42$28 \%$. Тобто, важкий дистрес плода при народженні мали $72 \%$ дітей (рис. 2).

Новонароджені мали велику кількість тяжких захворювань у неонатальному періоді, а недоношені новонароджені мали в 2,3 раза більше. Найтяжчими захворюваннями у неонатальному періоді, які вказують на тяжке гіпоксично-ішемічне ушкодження головного мозку, були внутрішньошлуночкові крововиливи (ВШК) у 27,3 \% недоношених новонароджених, ГІЕ у 59 (39,3\%) дітей в обох групах, набряк головного мозку у 12 (8\%) дітей в обох групах, кома у 5 (5,7 \%) недоношених новонароджених. Про ушкодження головного мозку свідчили розвиток синдрому збудження у кожної четвертої дитини, синдрому пригнічення у 37,5 \% недоношених дітей та судоми. Уроджена інфекція сприяє пошкодженню головного мозку, яку мали 31,8 \% недоношених новонароджених. Несприятливими фракторами ризику є розвиток РДС I та II типів, який мали 40 (26,7 \%) дітей в обох групах. Некротичний ентероколіт ускладнив стан новонароджених у $28-41,8$ \% недоношених новонароджених. Таким чином, наші дані свідчать, що діти, які мали гіпоксично-ішемічне ушкодження головного мозку, були у тяжкому стані, потребували інтенсивного лікування.

Отже, найбільші шанси ушкодження головного мозку мають новонароджені з уродженою інфекцією, ВШК 34 ст., ГІЕ, судомами, синдромом пригнічення, родовою травмою, тетрапарезом та лікуванням за допомогою ШВЛ (рис. 3). Вказані вище захворювання були вірогідно частішими у народжених жінками з другої групи, які були невчасно госпіталізовані з ускладненнями вагітності та пологів без профілактичних заходів для майбутніх дітей. Померли в перші 7 діб 3 дитини з групи порівняння. Причинами ранньої неонатальної смертності були ВШК 4 ст., родова травма, уроджена інсрекція. У першій групі випадків перинатальних втрат не було.

На наступному етапі нашого дослідження у разі загрози передчасних пологів проводили нейропротекцію всім вагітним із метою визначення маркерів пошкодження головного мозку плода. Всіх недоношених дітей ми поді-

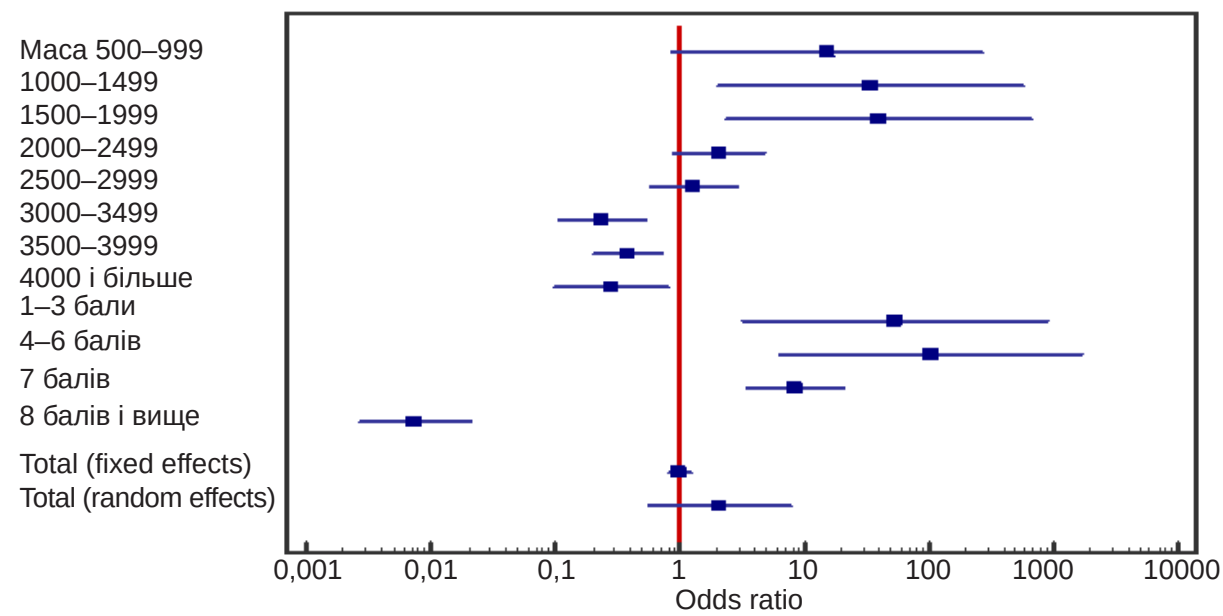

Рис. 2. Ризик розвитку ГІЕ залежно від маси тіла при народженні та оцінки за шкалою Апгар. 

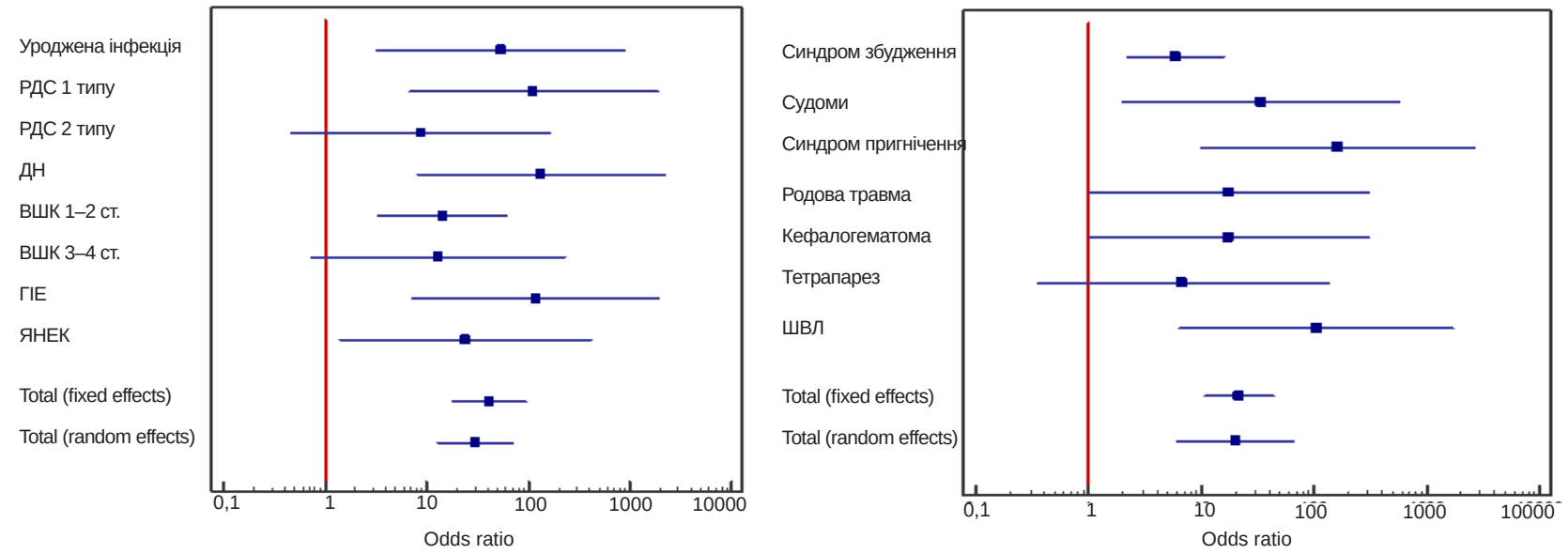

Рис. 3. Відношення шансів захворювань до гіпоксично-ішемічного ушкодження головного мозку в новонароджених.

лили на дві групи: основну групу склали 30 недоношених дітей, яким проводили нейропротекцію у терміні до 32 тижнів гестації. До групи порівняння увійшли також 30 недоношених дітей, народжених у терміні до 32 тижнів, яким за різними причинами не проводили нейропротекцію.

У травні 2011 р. Канадське товариство акушерів-гінекологів (SOGC) опублікувало клінічне керівництво під назвою «Сульфрат магнію для фретальної нейропротекції» (Magnesium Sulphate for Fetal Neuroprotection). Підставою для створення цього посібника послужила «проблема, пов'язана з успіхом». Сульфрат магнію для фретальної нейропротекції застосовують за схемою: навантажувальна доза 4 г внутрішньовенно протягом 30 хв із подальшою підтримувальною інфузією 1 г/год аж до народження дитини. Магній має кілька внутрішньоклітинних дій, включаючи протизапальну дію та пригнічення припливу кальцію до клітин [19, 20]. Один огляд Кокрана та метааналіз п'яти рандомізованих контрольованих досліджень (RCT) [21] продемонстрували, що сульфрат магнію ефективно знижує ризик розвитку ГIE (RR 0,69, 95 \% ДІ 0,55-0,88) та смертельних наслідків або церебрального паралічу (RR 0,86, 95 \% ДІ від 0,75 до 0,99).

\section{NSE Група порівняння} Апгар: LS Mears

Wilks lambda $=0,03085 F(6,34)=26,594, p=0,0000$

Effective hipothesis decomposition

Vertical bars denote 0,95 confidence interval

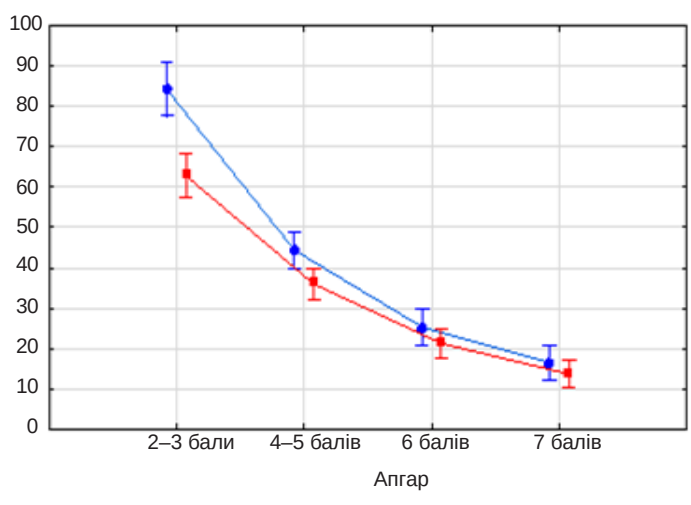

$z 32$
$\bar{y}>32$
Зростає доказ того, що поліненасичені жирні кислоти мають важливе значення для нормального розвитку мозку, сприяють народженню дитини з більшою масою і зменшують ризик передчасних пологів. Результати доклінічних та клінічних досліджень вказують на те, що приймання арахідонової та докозагексаєнової кислот під час вагітності має важливе значення для нейророзвитку та нейропротекції для недоношених дітей [22].

Одним із маркерів пошкодження нервової тканини $€$ нейрон-специфрічна енолаза (neuron-specificenolase-NSE) та білок S100B [23, 24]. Нейрон-специорічна енолаза (NSE) - це гліколітичний фрермент, який складається з димерів та визначається у високих концентраціях в нейронах і нейроендокринних клітинах, який каталізує перетворення 2-фросфогліцерату у фроссроенолпіруват. Підвищення рівня NSE у разі гіпоксичного пошкодження мозку плода прогнозує неврологічний десріцит. Високий рівень NSE асоціюється 3 несприятливими наслідками у новонароджених [25].

Таким чином, величина NSE була вірогідно вища у дітей $з$ терміном гестації до 32 тижнів та оцінкою за Апгар менше 6 балів (рис. 4).
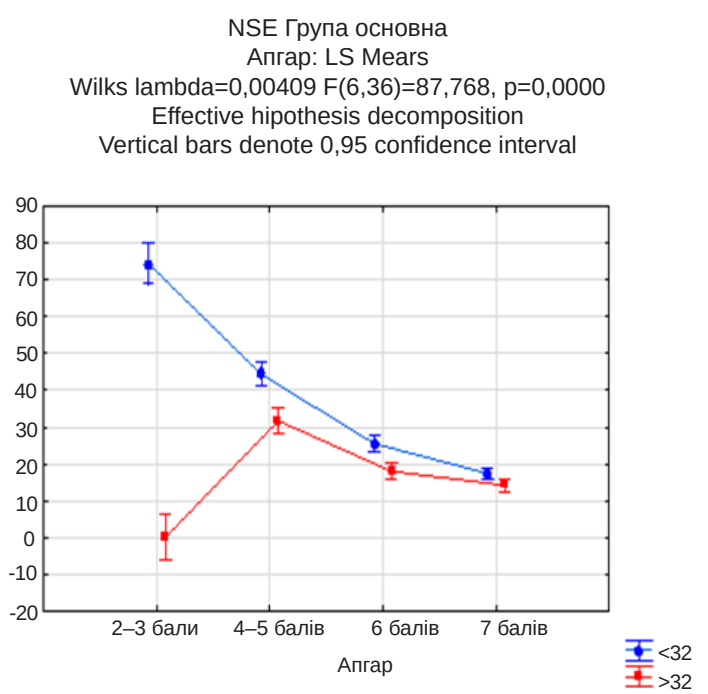

Рис. 4. Величина нейронспецифічної енолази (нг/мл) у недоношених новонароджених залежно від терміну гестації та оцінки за Апгар. 
Визначення концентрації білка S100 в біологічних рідинах дає необхідну інсрормацію про перинатальне пошкодження головного мозку після перинатальної ассріксії, ГІЕ і ВШК, фрізіологічний розвиток ЦНС у здорових новонароджених та ефективність медикаментозної терапії у вагітних та новонароджених [23, 25].

Найвища концентрація білка S100 була у глибоко недоношених дітей в терміні гестації до 32 тижнів та оцінкою за шкалою Апгар 2-3 бали (рис. 5). Нижча концентрація білка
S100 у новонароджених основної групи може пояснюватись проведенням для цих дітей нейропротекції сульфратом магнію перед розродженням, що має захисну дію на гіпоксичне пошкодження головного мозку. Концентрація білка S100 досягла майже нормального значення у новонароджених з оцінкою за шкалою Апгар 7 балів.

Таким чином, нейроспецифрічні маркери, як NSE та білок S100, можуть прогнозувати ступінь гіпоксичного ушкодження головного мозку новонароджених.

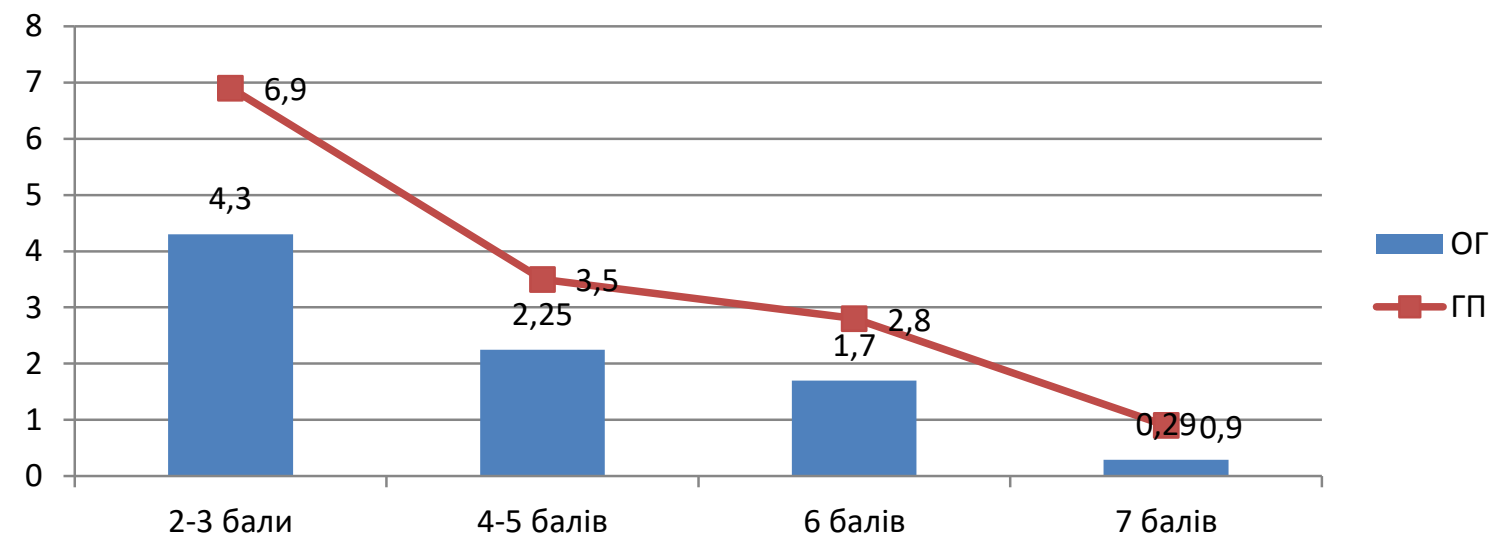

Рис. 5. Рівень білка S100 у недоношених новонароджених (мкг/л).

ВИСновкИ. 1. Факторами ризику неврологічних порушень у новонароджених $є$ наявність екстрагенітальної патології, урогенітальні захворювання у матері, недоношеність, такі ускладнення вагітності, як передчасний розрив плодових оболонок, розвиток хоріонамніоніту, затримка росту плода.

2. Діти з гіпоксично-ішемічним ушкодженням головного мозку мали низьку оцінку за шкалою Апгар, перебували у тяжкому стані після народження, потребували

\section{СПИСОК ЛІТЕРАТУРИ}

1. Антипкін Ю. Г. Стан здоров'я дитячого населення - майбутнє країни (частина 2) / Ю. Г. Антипкін, О. П. Волосовець, В. Г. Майданник // Здоров'я дитини. - 2018. - Т. 13, № 2. - С. 142-152.

2. Слабкий Г. О. Інвалідність дітей як проблема громадського здоров'я: профрілактика та забезпечення ефективної реабілітації / Г. О. Слабкий, В. В. Шафранський, О.О.Дудіна // Вісник соціальної гігієни та організації охорони здоров'я України. - 2016. - № 3 (69). - С. 4-9.

3. Стан здоров'я дітей 0-17 років включно за 2018 рік (аналітично-статистичний довідник). - К. : Центр медичної статистики МОЗ України, 2019. - 298 с.

4. Дудіна О. О. До стану здоров'я дитячого населення / О. О. Дудіна, Ю. Ю. Габорець, У. В. Волошина // Україна. Здоров'я нації. - 2015. - № 3. - С. 10-11.

5. Моісеєнко Р. О. Концепція соціальної педіатрії (комплексної медико-соціальної реабілітації дітей з обмеженнями життєдіяльності) / Р. О. Моісеєнко, В. Ю. Мартинюк // Реабілітація та паліативна медицина. - 2015. - № 1 (1). - С. 118-121.

6. Пальчик А. Б. Гипоксически-ишемическая энцесалопатия новорожденных / А. Б. Пальчик, Н. П. Шабалов. - 4-е изд., испр. и доп. - М. : МЕДпресс-информ, 2013. - 288 c. інтенсивного лікування. Недоношені новонароджені мали в 2,3 раза більший відсоток тяжких захворювань у неонатальному періоді.

3. Кваліфікований антенатальний нагляд, профрілактика передчасних пологів та народження дітей із низькою масою тіла, своєчасна діагностика гіпоксії плода та проведення нейропротекції сульсратом магнію перед розродженням $€$ важливими заходами попередження гіпоксично-ішемічного ушкодження головного мозку плода та новонародженого.

7. Preterm hypoxic-ischemic encephalopathy / K. R. Gopagondanahalli, J. Li, M. C. Fahey [et al.] // Front. Pediatr. - 2016. - Vol. 4. - P. 114.

8. Understanding the full spectrum of organ injury following intrapartum asphyxia / D. A. LaRosa, S. J. Ellery, D. W. Walker, H. Dickinson // Front. Pediatr. -2017. - Vol. 5. - P. 16.

9. Ante- and intrapartum risk factors for neonatal hypoxic ischemic encephalopathy / C. Lundgren, L. Brudin, A.-S. Wanby, M. Blomberg // J. Matern. Fetal. Neonatal. Med. - 2018. Vol. 31 (12). - P. 1595-1601.

10. Risk factors for perinatal arterial ischemic stroke: a casecontrol study / D. Munoz, M. J. Hidalgo, F. Balut [et al.] // Cell. Med. - 2018. - Vol. 10. - P. 2155179018785341.

11. Cerebral palsy among children born moderately and late preterm / M. Hirvonen, R. Ojala, P. Korhonen [et al.] // Pediatrics. - 2014. - Vol. 134 (6). - P. e1584-93.

12. 2 year neurodevelopmental and intermediate perinatal outcomes in infants with very preterm fetal growth restriction (TRUFFLE): a randomised trial / C. C. Lees, N. Marlow, A. van Wassenaer-Leemhuis [et al.] // Lancet. - 2015. Vol. 385 (9983). - P. 2162-2172.

13. Prognostic factors for cerebral palsy and motor impairment in children born very preterm or very low birthweight: 
a systematic review / L. Linsell, R. Malouf, J. Morris [et al.] // Dev. Med. Child. Neurol. - 2016. - Vol. 58 (6). - P. 554-569.

14. An update on the prevalence of cerebral palsy: a systematic review and meta-analysis / M. Oskoui, F. Coutinho, J. Dykeman [et al.] // Dev. Med. Child. Neurol. - 2013. Vol. 55 (6). - P. 509-519.

15. Cerebral palsy-trends in epidemology and recent development in prenatal mechanism of disease, treatment and prevention / M. Stavsky, O. Mor, S. A. Mastrolia [et al.] // Front. Pediatr. - 2017. - Vol. 5. - P. 21

16. Decreasing prevalence in cerebral palsy: a multi-site European population based-study 1980 to 2003 / E. Sellier, M. J. Platt, G. L. Anderson [et al.] // Dev. Med. Child. Neurol. 2016. - Vol. 58 (1). - P. 85-92.

17. Intrapartum fever and chorioamnionitis as risk for encephalopathy in term newborns: a case-control study I N. K. Blume, C. I. Li, C. M. Loch, T. D. Koepsell // Dev. Med. Child. Neurol. - 2008. - Vol. 50 (1). - P. 19-24.

18. Complex interactions between hypoxia-ischemia and inflammation in preterm -brain injury / R. Galinsky, C. A. Lear, J. M. Dean [et al.] // Dev. Med. Child. Neurol. - 2018. - Vol. 60 (2). - P. 126-133.

19. WHO Reproductive Health Library. WHO recommendation on the use of magnesium sulfate for fetal protection from neurological complications (November 2015). The
WHO Reproductive Health Library; Geneva: World Health Organization.

20. SOGC clinical practical guideline. Magnesium sulfate for fetal neuroprotection / L. Magee, D. DeSilva, D. Sawchuk, P. von Dadelszen // J. Obstet. Gynaecol. Can. - 2019. Vol. 41 (4). - P. 505-522.

21. Committee Opinion No 455: Magnesium sulfate before anticipated preterm birth for neuroprotection // J. Obset. Gynecol. - 2010. - Vol. 115 (3). - P. 669-671.

22. Klevebro S. A more comprehensive approach to the neuroprotective potential of long-chain polyunsaturated fatty acids in preterm infants is needed-should we consider maternal diet and the n-6:n-3 fatty acid ratio? / S. Klevebro, S. E. Juu, T. Wood // Front. Pediatr. - 2020. - Vol. 7. - P. 533.

23. Биомаркеры повреждения головного мозга у новорожденных / А. М. Приходько, А. Р. Киртбая, А. Ю. Романов, О. Р. Баев // Неонатология: новости, мнения, обучение. - 2018. - № 7 (1). - C. 70-76.

24. Brain-specific NSE and S-100 proteins in umbilical blood after normal delivery / I. Amer-Wåhlin, A. Herbst, C. Lindoff [at al.] // Clin. Chim. Acta. - 2001. - Vol. 304 (1-2). P. 57-63.

25. Serum S100B and neuron-specific enolase levels in normothermic and hypothermic infants after perinatal asphyxia / A. Roka, D. Kelen, J. Halasz [et al.] // Acta. Paediatr. - 2012. Vol. 101 (3). - P. 1184-1188.

\section{REFERENCES}

1. Antipkin, Yu.G., Volosovets, A.P., Maidannik, V.G., Berezenko, V.S., Moiseenko, R.A., Vygovskaya, O.V., ..., \& Mozyrskaya, E.V. (2018). Stan zdorovia dytiachoho naselennia - maibutnie krainy (chastyna 2) [Child health status - the future of the country (part 2)]. Zdorovia dytyny - Child Health, 13 (2), 142-152 [in Ukrainian].

2. Slabkiy, G.O., Shafranskiy, V.V., \& Dudina, O.O. (2016) Invalidnist ditei iak problema hromadskoho zdorovia: profilaktyka ta zabezpechennia efektyvnoi reabilitatsii [Disability of children as a problem of public health: prevention and effective rehabilitation]. Visnyk sotsialnoi hihiieny ta orhanizatsii okhorony zdorovia Ukrainy - Bulletin of Social Hygiene and Health Protection Organization of Ukraine, 3 (69), 4-9 DOI: https://doi. org/10.11603/1681-2786.2016.3.7002 [in Ukrainian].

3. (2019). Stan zdorovia ditei 0-17 rokiv vkliuchno za 2018 rik (analitychno-statystychnyi dovidnyk) [Child health status 0-17 years including for 2018 (analytical and statistical reference book)]. Kyiv: Tsentr medychnoi statystyky MOZ Ukrainy [in Ukrainian].

4. Dudina, O.O., Haborets, Yu.Yu., \& Voloshyna, U.V. (2015). Do stanu zdorovia dytiachoho naselennia [To the child health status]. Ukraina. Zdorovia natsii - Ukraine. The Health of the Nation, 3, 10-11 [in Ukrainian].

5. Moiseienko, R.O., \& Martyniuk, V.Yu. (2015). Kontseptsiia sotsialnoi pediatrii (kompleksnoi medyko-sotsialnoi reabilitatsii ditei z obmezhenniamy zhyttyediialnosti) [The concept of social pediatrics (complex medical and social rehabilitation of children with disabilities)]. Reabilitatsiia ta paliatyvna medytsyna - Rehabilitation and Palliative Medicine, 1 (1), 118-121 [in Ukrainian].

6. Palchik, A.B., \& Shabalov, N.P. (2013). Gipoksicheskiishemicheskaya entsefalopatiya novorozhdennykh [Finger AB Hypoxic-ischemic encephalopathy of newborns]. Moscow: MEDpress-inform [in Russian].

7. Gopagondanahalli, K.R., Li, J., Fahey, M.C., Hunt, R.W., Jenkin, G., Miller, S.L., \& Malhotra, A. (2016). Preterm hypoxicischemic encephalopathy. Front. Pediatr., 4, 114. DOI: 10.3389/ fped.2016.00114.
8. LaRosa, D.A., Ellery, S.J., Walker, D.W., \& Dickinson, H. (2017). Understanding the full spectrum of organ injury following intrapartum asphyxia. Front. Pediatr., 5, 16. DOI: 10.3389/ fped.2017.00016.

9. Lundgren, C., Brudin, L., Wanby, A.-S., \& Blomberg, M. (2018). Ante- and intrapartum risk factors for neonatal hypoxic ischemic encephalopathy. J. Matern. Fetal. Neonatal. Med., 31 (12), 1595-1601.

10. Munoz, D., Hidalgo, M.J., Balut, F., Troncoso, M., Lara, S., Barrios, A., Parra P. (2018). Risk factors for perinatal arterial ischemic stroke: a case-control study. Cell. Med., 10, 2155179018785341. DOI: 10.1177/2155179018785341.

11. Hirvonen, M., Ojala, R., Korhonen, P., Haataja, P., Eriksson, K., Gissler, M., ..., \& Tammela O. (2014). Cerebral palsy among children born moderately and late preterm. Pediatrics, 134 (6), e1584-93. DOI: 10.1542/peds.2014-0945.

12. Lees, C.C., Marlow, N., van Wassenaer-Leemhuis, A., Arabin, B., Bilardo, C.M., Brezinka, C., ..., \& Wolf, H. (2015). 2 year neurodevelopmental and intermediate perinatal outcomes in infants with very preterm fetal growth restriction (TRUFFLE): a randomised trial. Lancet, 385 (9983), 2162-2172. DOI: 10.1016/ S0140-6736(14)62049-3.

13. Linsell, L., Malouf, R., Morris, J., Kurinczuk, J.J., \& Marlow, N. (2016). Prognostic factors for cerebral palsy and motor impairment in children born very preterm or very low birthweight: a systematic review. Dev. Med. Child. Neurol., 58 (6), 554-569. DOI: 10.1111/dmcn.12972.

14. Oskoui, M., Coutinho, F., Dykeman, J., Jetté, N., \& Pringsheim, T. (2013). An update on the prevalence of cerebral palsy: a systematic review and meta-analysis. Dev. Med. Child. Neurol., 55 (6), 509-519. DOI: 10.1111/dmcn.12080.

15. Stavsky, M., Mor, O., Mastrolia, S.A., Greenbaum, S., Than, N.G., \& Erez, O. (2017). Cerebral palsy-trends in epidemology and recent development in prenatal mechanism of disease, treatment and prevention. Front. Pediatr., 5, 21. DOI: $10.3389 /$ fped.2017.00021.

16. Sellier, E., Platt, M.J., Anderson, G.L., Krägeloh-Mann, I., 
De La Cruz, J., Cans, C. (2016). Decreasing prevalence in cerebral palsy: a multi-site European population basedstudy 1980 to 2003. Dev. Med. Child. Neurol., 58 (1), 85-92. DOI: $10.1111 / \mathrm{dmcn} .12865$.

17. Blume, N.K., Li, C.I., Loch, C.M., \& Koepsell, T.D. (2008). Intrapartum fever and chorioamnionitis as risk for encephalopathy in term newborns: a case-control study. Dev. Med. Child. Neurol., 50 (1), 19-24. DOI: 10.1111/j.1469-8749.2007.02007.x.

18. Galinsky, R., Lear, C.A., Dean, J.M., Wassink, G., Dhillon, S.K., Fraser, M., ..., \& Gunn, A.J. (2018). Complex interactions between hypoxia-ischemia and inflammation in preterm -brain injury. Dev. Med. Child. Neurol., 60 (2), 126-133. DOI: $10.1111 / \mathrm{dmcn} .13629$.

19. WHO Reproductive Health Library. WHO recommendation on the use of magnesium sulfate for fetal protection from neurological complications (November 2015). The WHO Reproductive Health Library; Geneva: World Health Organization.

20. Magee, L., DeSilva, D., Sawchuk, D., \& von Dadelszen, P. (2019). SOGC clinical practical guideline. Magnesium sulfate for fetal neuroprotection. J. Obstet. Gynaecol. Can., 41 (4), 505522. DOI: 10.1016/S1701-2163(16)34886-1.
21. (2010). Committee Opinion No 455: Magnesium sulfate before anticipated preterm birth for neuroprotection. J. Obset. Gynecol., 115 (3), 669-671. DOI: 10.1097/AOG.0b013e3181d4ffa5.

22. Klevebro, S., Juu, S.E., \& Wood, T. (2020). A more comprehensive approach to the neuroprotective potential of longchain polyunsaturated fatty acids in preterm infants is neededshould we consider maternal diet and the n-6:n-3 fatty acid ratio? Front. Pediatr., 7, 533. DOI: 10.3389/fped.2019.00533.

23. Prikhodko, A.M., Kirtbaya, A.R., Romanov, A.Yu., \& Bayev, O.R. (2018). Biomarkery povrezhdeniya golovnogo mozga u novorozhdennykh [Biomarkers of brain damage in newborns]. Neonatologiya: novosti, mneniya, obucheniye Neonatology: News, Opinions, Training, 7 (1), 70-76 [in Russian].

24. Amer-Wåhlin, I., Herbst, A., Lindoff, C., ThorngrenJerneck, K., Marsál, K., \& Alling, C. (2001). Brain-specific NSE and S-100 proteins in umbilical blood after normal delivery. Clin. Chim. Acta., 304 (1-2), 57-63. DOI: 10.1016/s00098981(00)00408-3.

25. Roka, A., Kelen, D., Halasz, J., Beko, G., Azzopardi, D., \& Szabo, M. (2012). Serum S100B and neuron-specific enolase levels in normothermic and hypothermic infants after perinatal asphyxia. Acta. Paediatr., 101 (3), 1184-1188. DOI: 10.1111/j.1651-2227.2011.02480.x.

Отримано 24.09.20

Прийнято до друку 28.10.20

Електронна адреса для листування: sposohova@ukr.net 